Article

\title{
Synthesis and In Vitro Photodynamic Activity of Cationic Boron Dipyrromethene-Based Photosensitizers Against Methicillin-Resistant Staphylococcus aureus
}

\author{
Priyanga Dharmaratne ${ }^{1,+}\left(\mathbb{D}\right.$, Roy C. H. Wong ${ }^{2,+}$, Jun Wang ${ }^{3}$, Pui-Chi Lo ${ }^{3}$, Baiyan Wang ${ }^{1}$, \\ Ben C. L. Chan ${ }^{4,5}$ () , Kit-Man Lau ${ }^{4,5}$, Clara B. S. Lau ${ }^{4,5}$, Kwok-Pui Fung ${ }^{1,6}$, Margaret Ip ${ }^{7,8, *(1)}$ \\ and Dennis K. P. Ng ${ }^{2, *}$ \\ 1 School of Biomedical Sciences, Faculty of Medicine, The Chinese University of Hong Kong, \\ Shatin, N.T., Hong Kong; priyanga@cuhk.edu.hk (P.D.); tinawang@cuhk.edu.hk (B.W.); \\ kpfung@cuhk.edu.hk (K.-P.F.) \\ 2 Department of Chemistry, The Chinese University of Hong Kong, Shatin, N.T., Hong Kong; \\ roywongchihang@gmail.com \\ 3 Department of Biomedical Sciences, City University of Hong Kong, Tat Chee Avenue, Kowloon, Hong Kong; \\ junma9003@hfnu.edu.cn (J.W.); gigi.lo@cityu.edu.hk (P.-C.L.) \\ 4 Institute of Chinese Medicine, The Chinese University of Hong Kong, Shatin, N.T., Hong Kong; \\ benchan99@cuhk.edu.hk (B.C.L.C.); virginialau@cuhk.edu.hk (K.-M.L.); claralau@cuhk.edu.hk (C.B.S.L.) \\ 5 State Key Laboratory of Research on Bioactivities and Clinical Applications of Medicinal Plants, \\ The Chinese University of Hong Kong, Shatin, N.T., Hong Kong \\ 6 CUHK-Zhejiang University Joint Laboratory on Natural Products and Toxicology Research, \\ The Chinese University of Hong Kong, Shatin, N.T., Hong Kong \\ 7 Department of Microbiology, Faculty of Medicine, The Chinese University of Hong Kong, \\ Prince of Wales Hospital, Shatin, N.T., Hong Kong \\ 8 Shenzhen Research Institute, The Chinese University of Hong Kong, Shenzhen 518057, China \\ * Correspondence: margaretip@cuhk.edu.hk (M.I.); dkpn@cuhk.edu.hk (D.K.P.N.) \\ + These authors contributed equally to this work.
}

Received: 18 May 2020; Accepted: 26 May 2020; Published: 29 May 2020

check for updates

\begin{abstract}
A series of cationic boron dipyrromethene (BODIPY) derivatives were synthesized and characterized with various spectroscopic methods. Having the ability to generate singlet oxygen upon irradiation, these compounds could potentially serve as photosensitizers for antimicrobial photodynamic therapy. Of the five BODIPYs being examined, the dicationic aza-BODIPY analogue (compound 5) demonstrated the highest potency against a broad spectrum of clinically relevant methicillin-resistant Staphylococcus aureus (MRSA), including four ATCC-type strains (ATCC 43300, ATCC BAA-42, ATCC BAA-43, and ATCC BAA-44), two strains carrying specific antibiotic resistance mechanisms [-AAC(6')-APH(2") and RN4220/pUL5054], and ten non-duplicate clinical strains from hospital- and community-associated MRSAs of the important clonal types ST239, ST30, and ST59, which have previously been documented to be prevalent in Hong Kong and its neighboring countries. The in vitro anti-MRSA activity of compound 5 was achieved upon irradiation with near-infrared light $(>610 \mathrm{~nm}$ ) with minimal bactericidal concentrations (MBCs) ranging from 12.5 to $25 \mu \mathrm{M}$ against the whole panel of MRSAs, except the hospital-associated MRSAs for which the MBCs were in the range of 50-100 $\mu \mathrm{M}$. Compound 5 was significantly $(p<0.05)$ more potent than methylene blue, which is a clinically approved photosensitizer, indicating that it is a promising antimicrobial agent that is worthy of further investigation.
\end{abstract}


Keywords: antimicrobials; boron dipyrromethenes; methicillin-resistant Staphylococcus aureus; photodynamic therapy; photosensitizers

\section{Introduction}

Staphylococcus aureus remains the leading cause of hospital-associated infection and communityassociated infection around the globe, where a high proportion of these infections was caused by methicillin-resistant Staphylococcus aureus (MRSA) [1,2]. It is the causative pathogen for most of the skin and soft tissue infections (SSTIs), endovascular infections, pneumonia, septic arthritis, endocarditis, osteomyelitis, foreign-body infections, and sepsis and is unfortunately resistant to all available penicillins and other $\beta$-lactam antibiotics [3].

In 1961, soon after the introduction of methicillin, MRSA infections were first detected in hospitals (HA-MRSA) in the United Kingdom [4]. A decline in MRSA cases was observed in the 1970s, but a dramatic re-emergence of MRSA strains occurred in the early 1980s throughout the world, including the United Kingdom, USA, Australia, and some European countries (France, Italy, and Spain) [3-5].

The scarcity of effective therapies for highly pathogenic bacterial infections, including MRSA infections, stresses the need for the development of novel approaches for either treatment or prevention of these infections. Antimicrobial photodynamic therapy (aPDT) is such an alternative approach that is currently being explored as a potential therapeutic treatment option for various types of infections, including bacterial, fungal, viral, or even parasitic in nature [6-10]. It is conceptually simple and only requires a photosensitizer to generate reactive oxygen species (ROS), such as singlet oxygen, upon illumination with visible or near-infrared light [11]. This new treatment modality offers various advantages over the existing antimicrobial therapies. First, aPDT can combat multidrug-resistant strains due to its unique cytotoxic mechanism [12,13]. Second, it does not induce cytotoxicity in the absence of light irradiation. Hence, toxicity is largely confined to the photosensitizer-located and light-irradiated zone [14]. In addition, the inactivation of microorganisms by this method is usually rapid [15] and the photosensitizers show limited or no resistance so far [16-18].

While various classes of photosensitizers, including the tetrapyrrole-based macrocycles (e.g., porphyrins, bacteriochlorins, and phthalocyanines) [19-21], phenothiazine derivatives (e.g., methylene blue and Toludine Blue O) [22,23], and natural product derivatives (e.g., curcumin, riboflavin, and hypericin) [24-26], have been studied for their anti-MRSA activities, relatively little is known regarding the application of boron dipyrromethene (BODIPY)-based photosensitizers against MRSA infections. This class of functional dyes possesses tunable absorption and photophysical properties, ease of chemical modification, and high stability, and these dyes are therefore promising photosensitizers for PDT [27-30]. Frimannsson et al. reported a brominated aza-BODIPY and its non-brominated analogue for aPDT [31]. The former showed 6.8 and $3.4 \log _{10}$ colony-forming unit (CFU) reduction against methicillin-sensitive Staphylococcus aureus (MSSA) and MRSA strains, respectively, at a drug dose of $5 \mu \mathrm{g} / \mathrm{mL}$ with a light fluence of $16 \mathrm{~J} / \mathrm{cm}^{2}$. By contrast, the non-brominated counterpart was totally ineffective at the same concentration even when the fluence was increased to $25 \mathrm{~J} / \mathrm{cm}^{2}$. Carpenter et al. reported another aza-BODIPY derivative that was photodynamically active toward a broad spectrum of microbials including viruses, fungi, and bacteria [32]. It exhibited 5-6 $\log _{10}$ CFU reduction against MRSA ATCC-44 at a concentration as low as $0.1 \mu \mathrm{M}$. However, relatively few clinically relevant MRSAs have been explored, and there is a lack of understanding of this new class of photosensitizers against MRSA infections. We report herein the synthesis and photophysical properties of a series of cationic BODIPY derivatives and their in vitro antibacterial photodynamic activity against a broad spectrum of clinically relevant MRSA. 


\section{Materials and Methods}

\subsection{General Information}

All the reactions were performed under an atmosphere of nitrogen. Tetrahydrofuran (THF), $\mathrm{CH}_{2} \mathrm{Cl}_{2}$, and $\mathrm{N}$,N-dimethylformamide (DMF) were purified with an INERT solvent purification system (PS-MD-5, Amesbury, MA, USA), while all other solvents were used without further purification. Silica gel (Macherey-Nagel, Düren, Germany; 230-400 mesh) was used as the stationary phase for chromatographic purification. Compounds 6 [33], 7 [34], 13 [35], 15 [36], 16 [37], and 17 [38] were prepared according to the literature procedures.

${ }^{1} \mathrm{H}$ and ${ }^{13} \mathrm{C}\left\{{ }^{1} \mathrm{H}\right\}$ NMR spectra were recorded on a Bruker AVANCE III 500 spectrometer $\left({ }^{1} \mathrm{H}\right.$, $500 \mathrm{MHz} ;{ }^{13} \mathrm{C}, 125.0 \mathrm{MHz}$ ) or a Bruker AVANCE III 400 spectrometer (Billerica, MA, USA) $\left({ }^{1} \mathrm{H}, 400 \mathrm{MHz}\right.$; $\left.{ }^{13} \mathrm{C}, 100.6 \mathrm{MHz}\right)$ in $\mathrm{CDCl}_{3}$ or DMSO- $d_{6}$. Spectra were referenced internally by using the residual solvent $\left({ }^{1} \mathrm{H}, \delta=7.26\right.$ (for $\left.\mathrm{CDCl}_{3}\right), \delta=2.50$ (for DMSO- $\left.d_{6}\right)$ ) or solvent $\left({ }^{13} \mathrm{C}, \delta=77.2\right.$ (for $\left.\mathrm{CDCl}_{3}\right), \delta=39.5$ $\left(\right.$ for DMSO- $\left.d_{6}\right)$ ) resonances relative to $\mathrm{SiMe}_{4}$. Electrospray ionization (ESI) and matrix-assisted laser desorption/ionization time-of-flight (MALDI-TOF) mass spectra were recorded on a Thermo QEF MS mass spectrometer (Waltham, MA, USA) and a Bruker Autoflex speed MALDI-TOF mass spectrometer (Billerica, MA, USA), respectively. Electronic absorption and steady-state fluorescence spectra were taken on a Shimazu UV-1800 UV-Vis spectrophotometer (Tokyo, Tokyo Prefecture, Japan) and a Horiba FluoroMax spectrofluorometer (Kyoto, Kyoto Prefecture, Japan), respectively.

\subsection{Synthesis of BODIPY Derivatives}

Preparation of compound 8. Knoevenagel condensation of compound 6 ( $50 \mathrm{mg}, 95 \mu \mathrm{mol})$ and compound 7 (56 mg, $0.21 \mathrm{mmol})$ in the presence of glacial acetic acid $(0.2 \mathrm{~mL}, 4.6 \mathrm{mmol})$, piperidine $(0.25 \mathrm{~mL}, 2.9 \mathrm{mmol})$, and a small amount of $\mathrm{Mg}\left(\mathrm{ClO}_{4}\right)_{2}$ was carried out in toluene $(50 \mathrm{~mL})$. The mixture was heated under reflux for $16 \mathrm{~h}$, during which the water formed was removed azeotropically with a Dean-Stark apparatus. After evaporation in vacuo, the residue was purified by column chromatography using $\mathrm{CH}_{2} \mathrm{Cl}_{2} / \mathrm{MeOH}(20: 1, v / v)$ as the eluent (35 mg, 36\%). ${ }^{1} \mathrm{H} \mathrm{NMR}\left(400 \mathrm{MHz}, \mathrm{CDCl}_{3}\right) \delta 8.08(\mathrm{~d}$, $J=16.8 \mathrm{~Hz}, 2 \mathrm{H}, \mathrm{C}=\mathrm{CH}), 7.59-7.63(\mathrm{~m}, 6 \mathrm{H}, \mathrm{ArH}$ and $\mathrm{C}=\mathrm{CH}), 7.04(\mathrm{~d}, J=8.4 \mathrm{~Hz}, 2 \mathrm{H}, \mathrm{ArH}), 6.96(\mathrm{~d}$, $J=8.8 \mathrm{~Hz}, 4 \mathrm{H}, \mathrm{ArH}), 6.79(\mathrm{~d}, J=8.0 \mathrm{~Hz}, 2 \mathrm{H}, \mathrm{ArH}), 4.19\left(\mathrm{t}, J=4.8 \mathrm{~Hz}, 4 \mathrm{H}, \mathrm{CH}_{2}\right), 3.89(\mathrm{t}, J=4.8 \mathrm{~Hz}$, $\left.4 \mathrm{H}, \mathrm{CH}_{2}\right), 6.75-3.77\left(\mathrm{~m}, 4 \mathrm{H}, \mathrm{CH}_{2}\right), 3.66-3.71\left(\mathrm{~m}, 8 \mathrm{H}, \mathrm{CH}_{2}\right), 3.55-3.57\left(\mathrm{~m}, 4 \mathrm{H}, \mathrm{CH}_{2}\right), 3.39\left(\mathrm{~s}, 6 \mathrm{H}_{1} \mathrm{CH}_{3}\right)$, $3.04\left(\mathrm{~s}, 6 \mathrm{H}, \mathrm{NCH}_{3}\right), 1.52\left(\mathrm{~s}, 6 \mathrm{H}, \mathrm{CH}_{3}\right) .{ }^{13} \mathrm{C}\left\{{ }^{1} \mathrm{H}\right\} \mathrm{NMR}\left(\mathrm{CDCl}_{3}\right) \delta 14.2,40.5,59.2,67.7,69.8,70.7,70.8$, 71.0, 72.1, 109.9, 112.6, 115.1, 116.4, 122.0, 129.3, 129.4, 130.1, 132.8, 138.4, 140.6, 141.3, 148.0, 151.0, 160.0 . HRMS (ESI) Calcd. for $\mathrm{C}_{49} \mathrm{H}_{58} \mathrm{BBr}_{2} \mathrm{~F}_{2} \mathrm{~N}_{3} \mathrm{NaO}_{8}[\mathrm{M}+\mathrm{Na}]^{+}$1048.2538, found 1048.2544.

Preparation of compound 1. A mixture of compound 8 (15 mg, $15 \mu \mathrm{mol})$ and $\mathrm{CH}_{3} \mathrm{I}(104 \mathrm{mg}$, $0.73 \mathrm{mmol})$ in DMF (10 mL) was stirred at room temperature overnight. The product was obtained after precipitation in hexane followed by filtration and dried in vacuo $(14 \mathrm{mg}, 82 \%)$. ${ }^{1} \mathrm{H} \mathrm{NMR}(500 \mathrm{MHz}$, DMSO- $\left.d_{6}\right) \delta 8.21(\mathrm{~d}, J=8.5 \mathrm{~Hz}, 2 \mathrm{H}, \mathrm{ArH}), 8.10(\mathrm{~d}, J=16.5 \mathrm{~Hz}, 2 \mathrm{H}, \mathrm{C}=\mathrm{CH}), 7.84(\mathrm{~d}, J=8.5 \mathrm{~Hz}, 2 \mathrm{H}$, $\mathrm{ArH}), 7.63(\mathrm{~d}, J=8.5 \mathrm{~Hz}, 4 \mathrm{H}, \mathrm{ArH}), 7.49(\mathrm{~d}, J=16.5 \mathrm{~Hz}, 2 \mathrm{H}, \mathrm{C}=\mathrm{CH}), 7.10(\mathrm{~d}, J=8.5 \mathrm{~Hz}, 4 \mathrm{H}, \mathrm{ArH})$, $4.19(\mathrm{t}, J=4.5 \mathrm{~Hz}, 4 \mathrm{H}, \mathrm{CH} 2), 3.78\left(\mathrm{t}, J=4.5 \mathrm{~Hz}, 4 \mathrm{H}, \mathrm{CH}_{2}\right), 3.70\left(\mathrm{~s}, 9 \mathrm{H}, \mathrm{NCH}_{3}\right), 3.60-3.62(\mathrm{~m}, 4 \mathrm{H}$, $\left.\mathrm{CH}_{2}\right), 3.53-3.56\left(\mathrm{~m}, 8 \mathrm{H}, \mathrm{CH}_{2}\right), 3.43-3.45\left(\mathrm{~m}, 4 \mathrm{H}, \mathrm{CH}_{2}\right), 3.25\left(\mathrm{~s}, 6 \mathrm{H}, \mathrm{CH}_{3}\right), 1.40\left(\mathrm{~s}, 6 \mathrm{H}, \mathrm{CH}_{3}\right) .{ }^{13} \mathrm{C}\left\{{ }^{1} \mathrm{H}\right\}$ NMR (DMSO- $\left.d_{6}\right) \delta 13.8,56.6,58.1,67.5,68.9,69.7,69.9,70.0,71.3,109.9,115.0,115.4,121.8,128.7,129.2$, 130.5, 131.4, 135.7, 137.3, 139.0, 140.8, 147.9, 148.4, 160.2. HRMS (ESI) Calcd. for $\mathrm{C}_{50} \mathrm{H}_{61} \mathrm{BBr}_{2} \mathrm{~F}_{2} \mathrm{~N}_{3} \mathrm{NaO}_{8}$ $[\mathrm{M}+\mathrm{Na}]^{2+} 531.6384$, found 531.6384 .

Preparation of compound 10. A mixture of compound 6 (50 mg, $95 \mu \mathrm{mol})$, compound 9 (26 mg, $0.21 \mathrm{mmol})$, glacial acetic acid $(0.2 \mathrm{~mL}, 4.6 \mathrm{mmol})$, piperidine $(0.25 \mathrm{~mL}, 2.9 \mathrm{mmol})$, and a small amount of $\mathrm{Mg}\left(\mathrm{ClO}_{4}\right)_{2}$ in toluene $(50 \mathrm{~mL})$ was refluxed for $16 \mathrm{~h}$. The water formed during the reaction was removed azeotropically with a Dean-Stark apparatus. The mixture was concentrated under reduced pressure. The residue was purified by column chromatography using $\mathrm{CH}_{2} \mathrm{Cl}_{2} / \mathrm{MeOH}(10: 1, v / v)$ as the eluent (29 mg, 42\%). ${ }^{1} \mathrm{H}$ NMR (400 MHz, DMSO- $\left.d_{6}\right) \delta 10.07$ (s, $\left.2 \mathrm{H}, \mathrm{OH}\right), 8.00(\mathrm{~d}, J=16.8 \mathrm{~Hz}, 2 \mathrm{H}$, $\mathrm{C}=\mathrm{CH}), 7.49(\mathrm{~d}, J=8.4 \mathrm{~Hz}, 4 \mathrm{H}, \mathrm{ArH}), 7.39(\mathrm{~d}, J=16.8 \mathrm{~Hz}, 2 \mathrm{H}, \mathrm{C}=\mathrm{CH}), 7.15(\mathrm{~d}, J=8.4 \mathrm{~Hz}, 2 \mathrm{H}, \mathrm{ArH})$, 
$6.88(\mathrm{~d}, J=8.4 \mathrm{~Hz}, 4 \mathrm{H}, \mathrm{ArH}), 6.85(\mathrm{~d}, J=8.8 \mathrm{~Hz}, 2 \mathrm{H}, \mathrm{ArH}), 3.00\left(\mathrm{~s}, 6 \mathrm{H}, \mathrm{NCH}_{3}\right), 1.48\left(\mathrm{~s}, 6 \mathrm{H}, \mathrm{CH}_{3}\right)$. ${ }^{13} \mathrm{C}\left\{{ }^{1} \mathrm{H}\right\}$ NMR (DMSO- $d_{6}$ ) $\delta 13.8,54.9,109.2,112.1,114.2,116.2,120.3,127.2,129.2,132.1,138.6,140.8$, 140.9, 147.1, 150.9, 159.4, 162.3. HRMS (ESI) Calcd. for $\mathrm{C}_{35} \mathrm{H}_{29} \mathrm{BBr}_{2} \mathrm{~F}_{2} \mathrm{~N}_{3} \mathrm{O}_{2}$ [M-H] ${ }^{-}$732.0684, found 732.0682.

Preparation of compound 12. A mixture of compound 10 (20 mg, $27 \mu \mathrm{mol})$, compound $\mathbf{1 1}(10 \mathrm{mg}$, $0.12 \mathrm{mmol})$, and a catalytic amount of $p$-toluenesulfonic acid $(\mathrm{TsOH})$ in $\mathrm{CH}_{2} \mathrm{Cl}_{2}(10 \mathrm{~mL})$ was stirred for $2 \mathrm{~h}$. $\mathrm{Et}_{3} \mathrm{~N}$ was added to neutralize the acid and the volatile was removed under reduced pressure. The product was obtained after purification by column chromatography using $\mathrm{CH}_{2} \mathrm{Cl}_{2} / \mathrm{MeOH}(50: 1$, $v / v)$ as the eluent $(24 \mathrm{mg}, 98 \%) .{ }^{1} \mathrm{H}$ NMR $\left(400 \mathrm{MHz}, \mathrm{CDCl}_{3}\right) \delta 8.08(\mathrm{~d}, J=16.8 \mathrm{~Hz}, 2 \mathrm{H}, \mathrm{C}=\mathrm{CH})$, 7.60-7.65 (m, 6 H, ArH and C=CH), $7.10(\mathrm{~d}, J=8.8 \mathrm{~Hz}, 4 \mathrm{H}, \mathrm{ArH}), 7.05(\mathrm{~d}, J=8.4 \mathrm{~Hz}, 2 \mathrm{H}, \mathrm{ArH}), 6.80(\mathrm{~d}$, $J=8.4 \mathrm{~Hz}, 2 \mathrm{H}, \mathrm{ArH}), 5.50(\mathrm{t}, J=2.8 \mathrm{~Hz}, 2 \mathrm{H}, \mathrm{CH}), 3.88-3.94(\mathrm{~m}, 2 \mathrm{H}, \mathrm{CH}), 3.61-3.66(\mathrm{~m}, 2 \mathrm{H}, \mathrm{CH}), 3.05$ (s, $\left.6 \mathrm{H}, \mathrm{NCH}_{3}\right), 1.99-2.07(\mathrm{~m}, 2 \mathrm{H}, \mathrm{CH}), 1.88-1.91\left(\mathrm{~m}, 4 \mathrm{H}, \mathrm{CH}_{2}\right), 1.63-1.72\left(\mathrm{~m}, 6 \mathrm{H}, \mathrm{CH}_{2}\right), 1.53(\mathrm{~s}, 6 \mathrm{H}$, $\left.\mathrm{CH}_{3}\right) .{ }^{13} \mathrm{C}\left\{{ }^{1} \mathrm{H}\right\} \mathrm{NMR}\left(\mathrm{CDCl}_{3}\right) \delta 14.2,18.8,25.3,30.4,40.5,62.2,96.3,110.0,112.6,116.7,116.9,129.2$, 129.4, 130.8, 132.9, 138.5, 140.7, 141.3, 148.1, 151.0, 158.2. HRMS (ESI) Calcd. for $\mathrm{C}_{45} \mathrm{H}_{47} \mathrm{BBr}_{2} \mathrm{~F}_{2} \mathrm{~N}_{3} \mathrm{O}_{4}$ $[\mathrm{M}+\mathrm{H}]^{+}$902.1981, found 902.1970 .

Preparation of compound 2. A mixture of compound 12 (15 mg, $17 \mu \mathrm{mol})$ and $\mathrm{CH}_{3} \mathrm{I}(118 \mathrm{mg}$, $0.83 \mathrm{mmol})$ in DMF $(10 \mathrm{~mL})$ was stirred at room temperature overnight. The product was obtained after precipitation in hexane followed by filtration and dried in vacuo $(13 \mathrm{mg}, 90 \%) .{ }^{1} \mathrm{H} \mathrm{NMR}(500 \mathrm{MHz}$, DMSO- $\left.d_{6}\right) \delta 10.14(\mathrm{~s}, 2 \mathrm{H}, \mathrm{OH}), 8.19(\mathrm{~d}, J=9.0 \mathrm{~Hz}, 2 \mathrm{H}, \mathrm{ArH}), 8.04(\mathrm{~d}, J=16.5 \mathrm{~Hz}, 2 \mathrm{H}, \mathrm{C}=\mathrm{CH}), 7.79(\mathrm{~d}$, $J=9.0 \mathrm{~Hz}, 2 \mathrm{H}, \mathrm{ArH}), 7.51(\mathrm{~d}, J=9.0 \mathrm{~Hz}, 4 \mathrm{H}, \mathrm{ArH}), 7.40(\mathrm{~d}, J=16.5 \mathrm{~Hz}, 2 \mathrm{H}, \mathrm{C}=\mathrm{CH}), 6.89(\mathrm{~d}, J=9.0 \mathrm{~Hz}$, $4 \mathrm{H}, \mathrm{ArH}), 3.70\left(\mathrm{~s}, 9 \mathrm{H}, \mathrm{NCH}_{3}\right), 1.32\left(\mathrm{~s}, 6 \mathrm{H}, \mathrm{CH}_{3}\right) .{ }^{13} \mathrm{C}\left\{{ }^{1} \mathrm{H}\right\} \mathrm{NMR}\left(\mathrm{DMSO}-d_{6}\right) \delta 13.7,56.7,109.8,114.0$, 116.4, 121.8, 127.2, 129.5, 130.5, 131.3, 135.8, 136.7, 139.4, 140.5, 147.9, 148.4, 159.7. HRMS (ESI) Calcd. for $\mathrm{C}_{36} \mathrm{H}_{33} \mathrm{BBr}_{2} \mathrm{~F}_{2} \mathrm{~N}_{3} \mathrm{O}_{2}[\mathrm{M}]^{+}$748.0984, found 748.0973.

Preparation of compound 14. A mixture of compound 6 ( $50 \mathrm{mg}, 95 \mu \mathrm{mol})$, compound 13 (50 mg, $0.21 \mathrm{mmol})$, glacial acetic acid $(0.2 \mathrm{~mL}, 4.6 \mathrm{mmol})$, piperidine $(0.25 \mathrm{~mL}, 2.9 \mathrm{mmol})$, and a small amount of $\mathrm{Mg}\left(\mathrm{ClO}_{4}\right)_{2}$ in toluene $(50 \mathrm{~mL})$ was refluxed for $16 \mathrm{~h}$. The water formed during the reaction was removed azeotropically with a Dean-Stark apparatus. The mixture was concentrated under reduced pressure. The residue was purified by column chromatography using $\mathrm{CH}_{2} \mathrm{Cl}_{2} / \mathrm{MeOH}(20: 1, v / v)$ as the eluent (33 mg, 36\%). ${ }^{1} \mathrm{H}$ NMR $\left(500 \mathrm{MHz}, \mathrm{CDCl}_{3}\right) \delta 8.08(\mathrm{~d}, J=16.5 \mathrm{~Hz}, 2 \mathrm{H}, \mathrm{C}=\mathrm{CH}), 7.60-7.63(\mathrm{~m}, 6 \mathrm{H}$, ArH and $\mathrm{C}=\mathrm{CH}), 7.07(\mathrm{~d}, J=8.5 \mathrm{~Hz}, 2 \mathrm{H}, \mathrm{ArH}), 6.96(\mathrm{~d}, J=8.5 \mathrm{~Hz}, 4 \mathrm{H}, \mathrm{ArH}), 6.84(\mathrm{~d}, J=7.5 \mathrm{~Hz}, 2 \mathrm{H}$, ArH), 4.51 (quintet, $J=6.0 \mathrm{~Hz}, 2 \mathrm{H}, \mathrm{CH}), 4.20(\mathrm{dd}, J=6.5$ and $8.5 \mathrm{~Hz}, 2 \mathrm{H}, \mathrm{CH}), 4.12(\mathrm{dd}, J=5.5$ and $9.5 \mathrm{~Hz}, 2 \mathrm{H}, \mathrm{CH}), 4.01(\mathrm{dd}, J=5.5$ and $9.5 \mathrm{~Hz}, 2 \mathrm{H}, \mathrm{CH}), 3.93(\mathrm{dd}, J=6.0$ and $8.5 \mathrm{~Hz}, 2 \mathrm{H}, \mathrm{CH}), 3.06(\mathrm{~s}$, $\left.\left.6 \mathrm{H}, \mathrm{NCH}_{3}\right), 1.53\left(\mathrm{~s}, 6 \mathrm{H}, \mathrm{CH}_{3}\right), 1.49\left(\mathrm{~s}, 6 \mathrm{H}, \mathrm{CH}_{3}\right), 1.42\left(\mathrm{~s}, 6 \mathrm{H}, \mathrm{CH}_{3}\right) .{ }^{13} \mathrm{C}^{1}{ }^{1} \mathrm{H}\right\} \mathrm{NMR}\left(\mathrm{CDCl}_{3}\right) \delta$ 14.2, 25.5, 27.0, 40.7, 43.8, 67.0, 69.0, 74.1, 110.0, 112.9, 115.0, 116.6, 129.4, 130.4, 132.9, 138.4, 140.6, 141.4, 148.1, 159.7, 159.9 (some of the signals were overlapped). HRMS (ESI) Calcd. for $\mathrm{C}_{47} \mathrm{H}_{49} \mathrm{BBr}_{2} \mathrm{~F}_{2} \mathrm{~N}_{3} \mathrm{O}_{6}[\mathrm{M}-\mathrm{H}]^{-}$ 960.2054, found 960.2047 .

Preparation of compound 3. A mixture of compound $14(15 \mathrm{mg}, 16 \mu \mathrm{mol})$ and $\mathrm{CH}_{3} \mathrm{I}(111 \mathrm{mg}$, $0.78 \mathrm{mmol})$ in DMF $(10 \mathrm{~mL})$ was stirred at room temperature overnight. The product was obtained after precipitation in hexane followed by filtration and dried in vacuo $(13 \mathrm{mg}, 80 \%) .{ }^{1} \mathrm{H} \mathrm{NMR}(400 \mathrm{MHz}$, DMSO- $\left.d_{6}\right) \delta 8.22(\mathrm{~d}, J=9.2 \mathrm{~Hz}, 2 \mathrm{H}, \mathrm{ArH}), 8.09(\mathrm{~d}, J=16.8 \mathrm{~Hz}, 2 \mathrm{H}, \mathrm{C}=\mathrm{CH}), 7.83(\mathrm{~d}, J=8.8 \mathrm{~Hz}, 2 \mathrm{H}$, $\mathrm{ArH}), 7.62(\mathrm{~d}, J=8.8 \mathrm{~Hz}, 4 \mathrm{H}, \mathrm{ArH}), 7.48(\mathrm{~d}, J=16.8 \mathrm{~Hz}, 2 \mathrm{H}, \mathrm{C}=\mathrm{CH}), 7.09(\mathrm{~d}, J=8.8 \mathrm{~Hz}, 4 \mathrm{H}, \mathrm{ArH})$, 5.02-5.03 (m, $1 \mathrm{H}), 4.71-4.74(\mathrm{~m}, 1 \mathrm{H}), 4.09(\mathrm{dd}, J=4.0$ and $10.0 \mathrm{~Hz}, 2 \mathrm{H}, \mathrm{CH}), 3.95(\mathrm{dd}, J=6.0$ and $10.0 \mathrm{~Hz}, 2 \mathrm{H}, \mathrm{CH}), 3.81-3.84(\mathrm{~m}, 2 \mathrm{H}, \mathrm{CH}), 3.71\left(\mathrm{~s}, 9 \mathrm{H}, \mathrm{NCH}_{3}\right), 3.47\left(\mathrm{~d}, J=6.0 \mathrm{~Hz}, 4 \mathrm{H}, \mathrm{CH}_{2}\right), 1.37(\mathrm{~s}$, $6 \mathrm{H}, \mathrm{CH}_{3}$ ). HRMS (ESI) Calcd. for $\mathrm{C}_{42} \mathrm{H}_{45} \mathrm{BBr}_{2} \mathrm{~F}_{2} \mathrm{~N}_{3} \mathrm{O}_{6}[\mathrm{M}]^{+} 896.1722$, found 896.1720.

Preparation of compound 4. According to the procedure described for compound 8, compound 15 $(0.25 \mathrm{~g}, 0.34 \mathrm{mmol})$ was treated with compound $16(0.18 \mathrm{~g}, 0.75 \mathrm{mmol})$, glacial acetic acid $(0.40 \mathrm{~mL}$, $9.2 \mathrm{mmol})$, piperidine $(0.50 \mathrm{~mL}, 5.8 \mathrm{mmol})$, and a small amount of $\mathrm{Mg}\left(\mathrm{ClO}_{4}\right)_{2}$ in toluene $(50 \mathrm{~mL})$ under reflux for $3 \mathrm{~h}$. $\mathrm{CH}_{2} \mathrm{Cl}_{2} / \mathrm{MeOH}(50: 1, v / v)$ was used as the eluent for purification by column chromatography. The green fraction was collected and concentrated under reduced pressure. Without further purification, the crude intermediate product was further treated with $\mathrm{CH}_{3} \mathrm{I}$ in THF at room 
temperature overnight. The product was obtained after precipitation in hexane followed by filtration and dried in vacuo (187 mg, 38\%). ${ }^{1} \mathrm{H}$ NMR (400 MHz, DMSO- $\left.d_{6}\right) \delta 8.07$ (d, J = 16.4 Hz, $\left.2 \mathrm{H}, \mathrm{C}=\mathrm{CH}\right)$, $7.62(\mathrm{~d}, J=8.8 \mathrm{~Hz}, 4 \mathrm{H}, \mathrm{ArH}), 7.43(\mathrm{~d}, J=16.4 \mathrm{~Hz}, 2 \mathrm{H}, \mathrm{C}=\mathrm{CH}), 7.34(\mathrm{~d}, J=8.8 \mathrm{~Hz}, 2 \mathrm{H}, \mathrm{ArH}), 7.17(\mathrm{~d}$, $J=8.8 \mathrm{~Hz}, 2 \mathrm{H}, \mathrm{ArH}), 7.09(\mathrm{~d}, J=8.8 \mathrm{~Hz}, 4 \mathrm{H}, \mathrm{ArH}), 4.15-4.19\left(\mathrm{~m}, 6 \mathrm{H}, \mathrm{CH}_{2}\right), 3.81\left(\mathrm{br} \mathrm{s}, 2 \mathrm{H}, \mathrm{CH}_{2}\right)$, 3.51-3.64 (m, $\left.10 \mathrm{H}, \mathrm{CH}_{2}\right), 3.40-3.46\left(\mathrm{~m}, 10 \mathrm{H}, \mathrm{CH}_{2}\right), 3.25\left(\mathrm{~s}, 3 \mathrm{H}, \mathrm{CH}_{3}\right), 2.98\left(\mathrm{~s}, 6 \mathrm{H}, \mathrm{CH}_{3}\right), 2.17(\mathrm{br} \mathrm{s}, 4 \mathrm{H}$, $\left.\mathrm{CH}_{2}\right), 1.48\left(\mathrm{~s}, 6 \mathrm{H}, \mathrm{CH}_{3}\right), 1.25\left(\mathrm{t}, J=7.2 \mathrm{~Hz}, 12 \mathrm{H}, \mathrm{CH}_{3}\right)$.

Preparation of compound 18. A mixture of compound 17 (200 mg, $0.23 \mathrm{mmol}), 1,6$-dibromohexane $(228 \mathrm{mg}, 0.93 \mathrm{mmol})$, and $\mathrm{K}_{2} \mathrm{CO}_{3}(129 \mathrm{mg}, 0.93 \mathrm{mmol})$ in $\mathrm{DMF}(20 \mathrm{~mL})$ was stirred at $70-80{ }^{\circ} \mathrm{C}$ for $8 \mathrm{~h}$. After cooling, the volatile was evaporated in vacuo. The residue was re-dissolved in $\mathrm{CH}_{2} \mathrm{Cl}_{2}(50 \mathrm{~mL})$, washed with water $(50 \mathrm{~mL} \times 3)$, and concentrated under reduced pressure. The residue was purified by column chromatography using $\mathrm{CHCl}_{3} /$ ethyl acetate $(2: 1 \mathrm{v} / \mathrm{v})$ as the eluent to give the product as a dark blue solid (179 mg, 65\%). ${ }^{1} \mathrm{H}$ NMR $\left(400 \mathrm{MHz}, \mathrm{CDCl}_{3}\right) \delta 8.08-8.05$ (m, $\left.8 \mathrm{H}, \mathrm{ArH}\right), 6.99-7.04$ (m, $8 \mathrm{H}$, $\mathrm{ArH}), 6.95\left(\mathrm{~s}, 2 \mathrm{H}\right.$, pyrrole-H), $4.26\left(\mathrm{t}, J=4.8 \mathrm{~Hz}, 4 \mathrm{H}, \mathrm{OCH}_{2}\right), 4.07\left(\mathrm{t}, J=6.4 \mathrm{~Hz}, 4 \mathrm{H}, \mathrm{OCH}_{2}\right), 3.95(\mathrm{t}$, $\left.J=4.8 \mathrm{~Hz}, 4 \mathrm{H}, \mathrm{OCH}_{2}\right), 3.79-3.82\left(\mathrm{~m}, 4 \mathrm{H}, \mathrm{OCH}_{2}\right), 3.73-3.76\left(\mathrm{~m}, 4 \mathrm{H}, \mathrm{OCH}_{2}\right), 3.69-3.71\left(\mathrm{~m}, 4 \mathrm{H}, \mathrm{OCH}_{2}\right)$, 3.58-3.60 (m, $\left.4 \mathrm{H}, \mathrm{OCH}_{2}\right), 3.47\left(\mathrm{t}, \mathrm{J}=6.8 \mathrm{~Hz}, 4 \mathrm{H}, \mathrm{CH}_{2} \mathrm{Br}\right), 3.41\left(\mathrm{~s}, 6 \mathrm{H}, \mathrm{OCH}_{3}\right), 1.92-1.96\left(\mathrm{~m}, 4 \mathrm{H}_{1} \mathrm{CH}_{2}\right)$, 1.84-1.87 (m, $\left.4 \mathrm{H}, \mathrm{CH}_{2}\right), 1.55$ (br s, $\left.8 \mathrm{H}, \mathrm{CH}_{2}\right)$.

Preparation of compound 19. A mixture of compound 18 (160 mg, $0.13 \mathrm{mmol}), 4,4^{\prime}$-dipyridine (847 mg, $5.42 \mathrm{mmol}), \mathrm{NaI}(203 \mathrm{mg}, 1.35 \mathrm{mmol})$, and $\mathrm{NaHCO}_{3}(187 \mathrm{mg}, 2.23 \mathrm{mmol})$ in acetone $(30 \mathrm{~mL})$ was stirred under reflux for 3 days. After cooling, the solvent was removed under reduced pressure. The residue was re-dissolved in $\mathrm{CHCl}_{3}(50 \mathrm{~mL})$, washed with water $(50 \mathrm{~mL} \times 3)$, and concentrated under reduced pressure. The mono-substituted aza-BODIPY was removed by column chromatography using $\mathrm{CH}_{2} \mathrm{Cl}_{2} / \mathrm{MeOH}(10: 1 \mathrm{v} / \mathrm{v})$ as the eluent. The desired product $(90 \mathrm{mg}, 42 \%)$ was obtained by changing the eluent to $\mathrm{CH}_{3} \mathrm{NO}_{2} / 2 \mathrm{M}$ aq. $\mathrm{NH}_{4} \mathrm{Cl} / \mathrm{MeOH} /$ acetone (5:10:50:35 v/v/v/v). ${ }^{1} \mathrm{H} \mathrm{NMR}(400 \mathrm{MHz}$, $\mathrm{CDCl}_{3}$ ) $\delta 9.58$ (br s, $4 \mathrm{H}, \mathrm{ArH}$ ), 8.76 (br s, $\left.4 \mathrm{H}, \mathrm{ArH}\right), 8.28$ (br s, $\left.4 \mathrm{H}, \mathrm{ArH}\right), 8.05$ (d, J = 8.0 Hz, $4 \mathrm{H}$, ArH), 7.96 (d, J = 8.0 Hz, 4 H, ArH), 7.66 (br s, 4 H, ArH), 7.02 (d, J = 8.0 Hz, 4 H, ArH), 6.91 (br s, 2 H, pyrrole-H), $6.82(\mathrm{~d}, \mathrm{~J}=8.0 \mathrm{~Hz}, 4 \mathrm{H}, \mathrm{ArH}), 5.02\left(\mathrm{br} \mathrm{s}, 4 \mathrm{H}, \mathrm{CH}_{2} \mathrm{~N}^{+}\right), 4.24\left(\mathrm{br} \mathrm{s}, 4 \mathrm{H}, \mathrm{OCH}_{2}\right), 3.94(\mathrm{br} \mathrm{s}, 8 \mathrm{H}$, $\mathrm{OCH}_{2}$ ), 3.80 (br s, $4 \mathrm{H}, \mathrm{OCH}_{2}$ ), 3.74 (br s, $4 \mathrm{H}, \mathrm{OCH}_{2}$ ), 3.69 (br s, $4 \mathrm{H}, \mathrm{OCH}_{2}$ ), 3.59 (br s, 4 H, OCH$)_{2}$, 3.41 (s, $6 \mathrm{H}, \mathrm{OCH}_{3}$ ), 2.06 (br s, $4 \mathrm{H}, \mathrm{CH}_{2}$ ), 1.75 (br s, $4 \mathrm{H}, \mathrm{CH}_{2}$ ), 1.43-1.52 (m, $8 \mathrm{H}, \mathrm{CH}_{2}$ ). MS (ESI): 666.2 $\left(100 \%, \mathrm{M}^{2+}\right)$.

Preparation of compound 5. A mixture of compound 19 (30 mg, $0.02 \mathrm{mmol})$ and bromine $(20 \mu \mathrm{L}$, $0.39 \mathrm{mmol})$ in $\mathrm{CH}_{2} \mathrm{Cl}_{2}(10 \mathrm{~mL})$ was stirred at room temperature for $40 \mathrm{~min}$. The reaction was monitored by UV-Vis spectrophotometer as the absorption band of compound 19 was blue-shifted after the addition of bromine atoms at the pyrrole rings. The solution was then diluted with $\mathrm{CH}_{2} \mathrm{Cl}_{2}$ and washed with $\mathrm{Na}_{2} \mathrm{~S}_{2} \mathrm{O}_{4}$ aqueous solution and water twice. The crude product was purified by recrystallization from $\mathrm{CH}_{2} \mathrm{Cl}_{2}$ and hexane as a dark blue solid $(20 \mathrm{mg}, 65 \%) .{ }^{1} \mathrm{H} \mathrm{NMR}\left(400 \mathrm{MHz}, \mathrm{CDCl}_{3}\right) \delta 9.07$ (br s, $4 \mathrm{H}, \mathrm{ArH}$ ), 8.66 (br s, 4 H, ArH), 8.26 (br s, 4 H, ArH), 7.81 (br s, 4 H, ArH), 7.66 (br s, 4 H, ArH), 7.58 (br s, 4 H, ArH), 6.91 (br s, $4 \mathrm{H}, \mathrm{ArH}), 6.66$ (br s, $4 \mathrm{H}, \mathrm{ArH}), 4.67$ (br s, $\left.4 \mathrm{H}, \mathrm{CH}_{2} \mathrm{~N}^{+}\right), 4.16$ (br s, $4 \mathrm{H}$, $\left.\mathrm{OCH}_{2}\right), 3.88\left(\right.$ br s, $\left.4 \mathrm{H}, \mathrm{OCH}_{2}\right), 3.74-3.76\left(\mathrm{~m}, 4 \mathrm{H}, \mathrm{OCH}_{2}\right), 3.68-3.70\left(\mathrm{~m}, 4 \mathrm{H}, \mathrm{OCH}_{2}\right), 3.64-3.66(\mathrm{~m}, 8 \mathrm{H}$, $\left.\mathrm{OCH}_{2}\right), 3.53-3.55\left(\mathrm{~m}, 4 \mathrm{H}, \mathrm{OCH}_{2}\right), 3.36\left(\mathrm{~s}, 6 \mathrm{H}, \mathrm{OCH}_{3}\right), 1.96$ (br s, $\left.4 \mathrm{H}, \mathrm{CH}_{2}\right), 1.58\left(\right.$ br s, 4 H, $\left.\mathrm{CH}_{2}\right), 1.34$ (br s, $\left.8 \mathrm{H}, \mathrm{CH}_{2}\right) .{ }^{13} \mathrm{C}\left\{{ }^{1} \mathrm{H}\right\} \mathrm{NMR}\left(\mathrm{CDCl}_{3}\right) \delta 15.3,25.5,25.8,28.8,31.5,59.2,61.5,66.8,67.6,67.9,69.7,69.9$, 70.7, 70.8, 71.0, 72.0, 108.8, 113.8, 114.3, 122.1, 123.5, 126.0, 132.5, 141.5, 142.2, 144.1, 145.7, 150.9, 152.7, $157.1,160.3,160.9$ (some of the signals were overlapped). HRMS (ESI) Calcd. for $\mathrm{C}_{78} \mathrm{H}_{86} \mathrm{BBr}_{2} \mathrm{~F}_{2} \mathrm{~N}_{7} \mathrm{O}_{10}$ $[\mathrm{M}]^{2+} 744.7428$, found 744.7453 .

\subsection{Determination of Fluorescence Quantum Yields}

The fluorescence quantum yields were determined according to the previously described method [39] using unsubstituted zinc(II) phthalocyanine $(\mathrm{ZnPc})$ in DMF as the reference $\left(\Phi_{\mathrm{F}}=0.28\right)$. 


\subsection{Determination of Singlet Oxygen Quantum Yields}

To determine the singlet oxygen quantum yields of the BODIPY derivatives, they (at $1 \mu \mathrm{M})$ were mixed with the singlet oxygen probe 1,3-diphenylisobenzofuran (DPBF) $(30 \mu \mathrm{M})$ in DMF. The decrease in absorbance of DPBF at $415 \mathrm{~nm}$ was monitored during irradiation. The light source consisted of a $100 \mathrm{~W}$ halogen lamp, a water tank for cooling, and a color filter with a cut-on wavelength at $610 \mathrm{~nm}$ (Newport, Irvine, CA, USA). The singlet oxygen quantum yields $\left(\Phi_{\Delta}\right)$ of the samples were determined by the equation $\Phi_{\Delta}($ sample $)=\left(\mathrm{W}_{\text {sample }} / \mathrm{W}_{\text {ref }}\right)\left(\mathrm{I}_{\text {ref }} / \mathrm{I}_{\text {sample }}\right) \Phi_{\Delta}($ ref $)$, where $\mathrm{W}$ and I are the DPBF photobleaching rate and the rate of light absorption, respectively [40]. Unsubstituted ZnPc in DMF was used as the reference $\left(\Phi_{\Delta}=0.56\right)$.

\subsection{Bacterial Strains and Culture Conditions}

The bacterial strains, including four ATCC-type MRSA (ATCC 43300, ATCC BAA-42, ATCC BAA-43, and ATCC BAA-44) and two antibiotic resistant SA [AAC(6')-APH(2") and RN4220/pUL5054] strains were used for the study. The AAC $\left(6^{\prime}\right)-\mathrm{APH}\left(2^{\prime \prime}\right)$-strain expresses the bi-functional enzyme $\mathrm{AAC}\left(6^{\prime}\right)-\mathrm{APH}\left(2^{\prime \prime}\right)$, which is an aminoglycoside-modifying enzyme conferring high-level gentamicin resistance (minimum inhibitory concentration (MIC): >128 $\mu \mathrm{g} / \mathrm{mL}$ ). The RN4220/pUL5054 strain over-expresses the $m s r(\mathrm{~A})$ gene encoding for an ATP-binding cassette $(\mathrm{ABC})$ transporter that induces resistance against erythromycin (MIC: $128 \mu \mathrm{g} / \mathrm{mL}$ ) [41]. Ten non-duplicate clinical isolates, namely 5 hospital-associated (HA) and 5 community-associated (CA) MRSAs, were included. They include the important clonal types ST239, ST30, and ST59 previously documented to be prevalent in Hong Kong and in neighboring countries [42-44]. All MRSA strains were grown in Mueller-Hinton Broth (MHB) for $18 \mathrm{~h}$ at $37^{\circ} \mathrm{C}$. The overnight culture suspension was adjusted to McFarland 0.5 and suspended in MHB to make a final concentration of $1.0 \times 10^{6} \mathrm{CFU} / \mathrm{mL}$. Altogether, $16 \mathrm{MRSA}$ strains (6 ATCC-type strains and 10 clinical non-duplicate isolates) were included for in vitro aPDT studies.

\subsection{In Vitro Photodynamic Minimal Bactericidal Concentration (PD-MBC) Studies}

Minimal bactericidal concentrations (MBCs) of BODIPY derivatives 1-5 and methylene blue were determined according to the Clinical and Laboratory Standards Institute (CLSI) guidelines [45] against 16 strains in 96-well microtiter plates. Briefly, photosensitizer solutions for PDT study were prepared freshly by dissolving compounds 1-5 in dimethyl sulfoxide (DMSO) to make $10 \mathrm{mM}$ stock solutions. They were then diluted with Tween 80 and MHB by a serial two-fold dilution procedure to obtain final working concentrations. Tween 80 and DMSO concentrations were maintained at or below $0.1 \%$ and $1 \%(v / v)$, respectively. Aliquots of this suspension $(200 \mu \mathrm{L})$ was incubated at $37^{\circ} \mathrm{C}$ for $120 \mathrm{~min}$ in the dark. Selected plates were illuminated from above with light intensity $40 \mathrm{~mW} / \mathrm{cm}^{2}$ using a $300 \mathrm{~W}$ quartz-halogen lamp attenuated by a $5 \mathrm{~cm}$ layer of water (heat buffer) and a color glass filter with a cut-on wavelength of 610 nm (65CGA-610, Newport, Franklin, MA, USA). The intrinsic toxicity (dark toxicity) of each compound was determined by samples of each microbial suspension that were incubated with each compound separately in the dark for $140 \mathrm{~min}$, corresponding to the pre-irradiation and illumination times. The effect of PDT alone was verified by adding $100 \mu \mathrm{L}$ of PBS and irradiating for $20 \mathrm{~min}\left(48 \mathrm{~J} / \mathrm{cm}^{2}\right)$. The untreated control group (negative control) did not receive any photosensitizers nor light. Solvent toxicity (blank control) was also evaluated with $0.1 \%$ Tween 80 and $1 \%$ DMSO $(v / v)$ to mimic the in vitro aPDT assay. The positive control groups were incubated with varied concentrations of methylene blue for $120 \mathrm{~min}$ followed by light illumination for $20 \mathrm{~min}$. After the PDT, the plates were re-incubated at $37^{\circ} \mathrm{C}$ overnight under dark conditions. To determine the MBC, the treated broth culture from wells that did not show any visible growth was cultured $(10 \mu \mathrm{L})$ on freshly prepared sterile blood agar plates. The least concentration (highest dilution) of the compound that completely inhibited colony formation on a solid agar medium after incubation at $35^{\circ} \mathrm{C}$ for $24 \mathrm{~h}$ was considered as MBC. Each experiment was carried out in triplicate and the range of $\mathrm{MBC}$ values was reported. 


\section{Results and Discussion}

\subsection{Synthesis of Cationic BODIPY Derivatives}

A series of mono- and di-cationic BODIPY derivatives (compounds 1-5) were designed and synthesized. Other than the cationic moieties, different hydrophilic groups were also introduced to increase the water solubility of the compounds and allow study of their effects on the aPDT efficiency. Scheme 1 shows the synthetic routes used to prepare distyryl BODIPYs 1-3 using the previously reported BODIPY 6 as a starting material. Knoevenagel condensation of compound 6 with the triethylglycol-substituted benzaldehyde 7 led to the formation of the distyryl analogue 8, which was then $\mathrm{N}$-methylated with $\mathrm{CH}_{3} \mathrm{I}$ in DMF to afford the ammonium distyryl BODIPY 1. Similarly, by using 4-hydroxybenzaldehyde (9) to condense with compound 6 using a molecular sieve as the dehydrating agent, the dihydroxy distyryl BODIPY $\mathbf{1 0}$ was obtained. The hydroxyl groups of this compound were then protected by treating the compound with 3,4-dihydro-2H-pyran (11) in the presence of a catalytic amount of $\mathrm{TsOH}$. The resulting compound 12 was then treated with $\mathrm{CH}_{3} \mathrm{I}$ in DMF to give compound $\mathbf{2}$, in which the protective groups were removed under this reaction condition. To study the effect of hydroxy groups, the tetrahydroxy analogue 3 was also prepared. Knoevenagel condensation of compound 6 with the isopropylidene glycerol-substituted benzaldehyde 13 gave distyryl BODIPY 14. Upon treatment with $\mathrm{CH}_{3} \mathrm{I}$ in DMF, the compound underwent one-pot deprotection and $N$-methylation to afford the target compound 3.

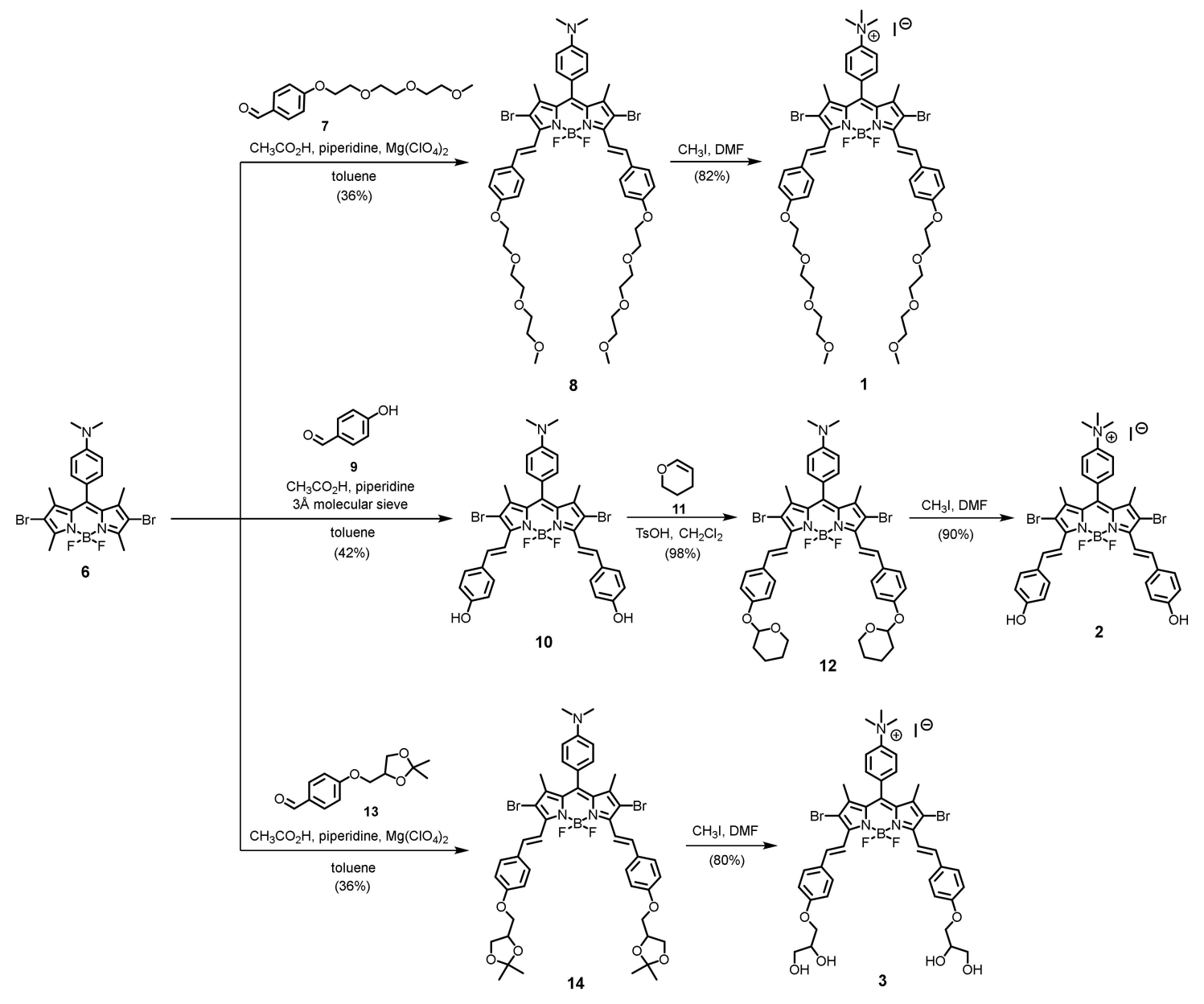

Scheme 1. Synthesis of mono-cationic distyryl boron dipyrromethenes (BODIPYs) 1-3. 
To study the effect of cationic moieties on the aPDT efficiency, we also prepared two dicationic analogues (compounds 4 and 5). As shown in Scheme 2, treatment of the previously reported BODIPY 15 with 4-[3-(diethylamino)propoxy]benzaldehyde (16) under typical reaction conditions of Knoevenagel condensation resulted in the formation of the distyryl BODIPY intermediate product, which was not purified and $N$-methylated directly in THF to give the dicationic analogue 4. Apart from distyryl BODIPYs, we also studied the aza-BODIPY derivatives that are also promising near-infrared-absorbing photosensitizers [46]. The synthetic route used to prepare the aza-BODIPY analogue 5 is shown in Scheme 3. O-Alkylation of compound $\mathbf{1 7}$ with an excess of 1,6-dibromohexane in the presence of $\mathrm{K}_{2} \mathrm{CO}_{3}$ in DMF led to the formation of compound 18, which underwent further nucleophilic substitution with 4,4'-dipyridine in the presence of $\mathrm{NaI}$ and $\mathrm{NaHCO}_{3}$ in acetone to afford the dicationic analogue 19. Finally, bromination of compound 19 using bromine in $\mathrm{CH}_{2} \mathrm{Cl}_{2}$ gave the expected product 5. The introduction of these heavy bromine atoms is essential in order to enable the compound to generate singlet oxygen by promoting the intersystem crossing through the heavy-atom effect.

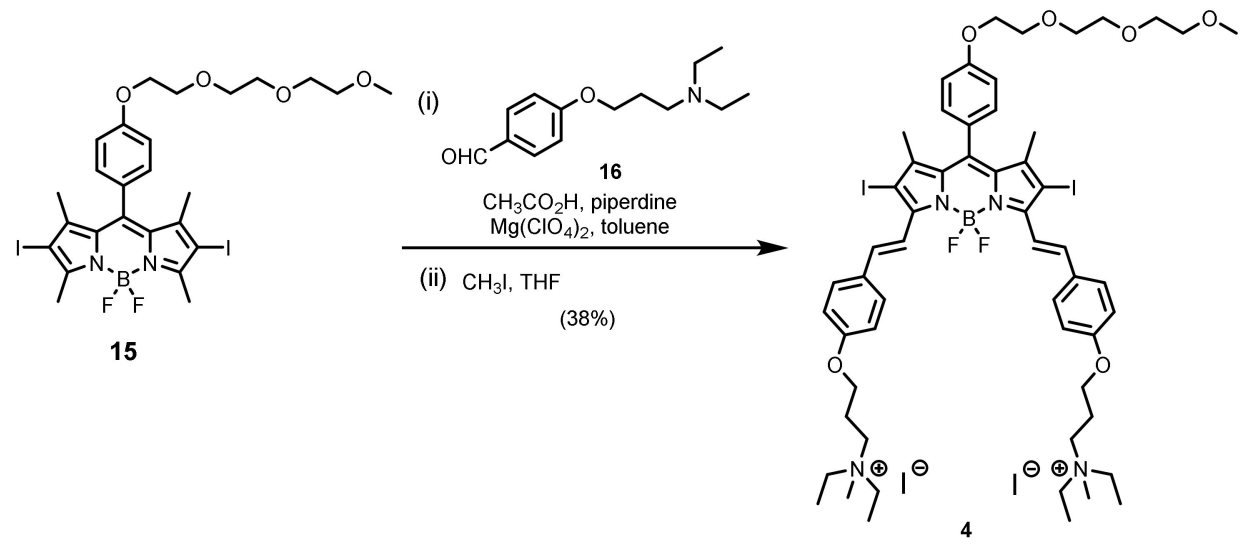

Scheme 2. Synthesis of dicationic distyryl BODIPY 4.

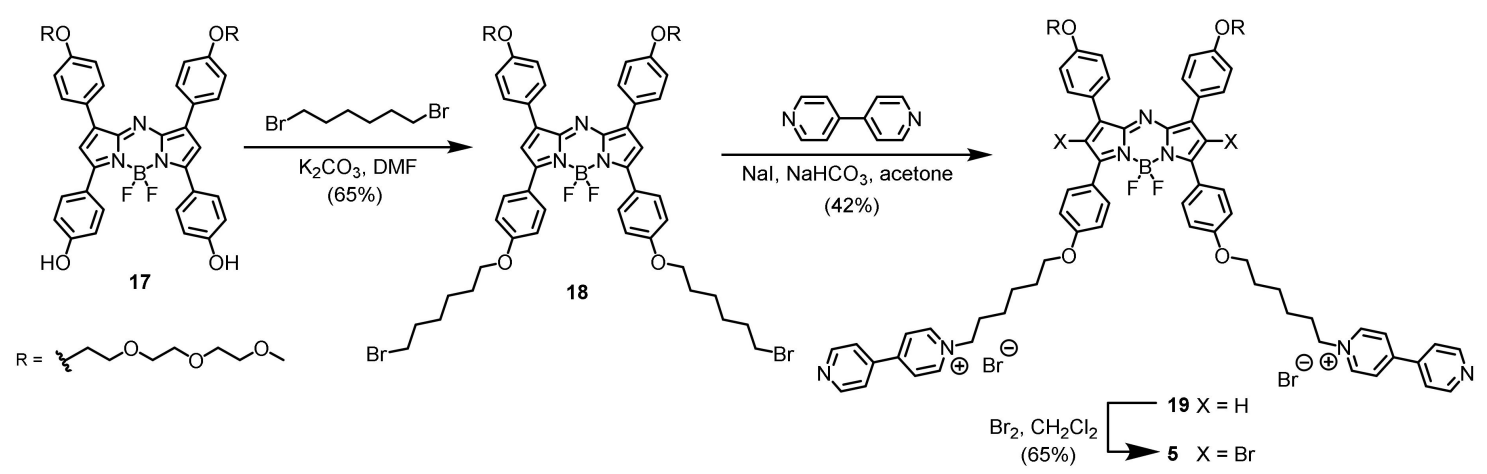

Scheme 3. Synthesis of dicationic aza-BODIPY 5.

\subsection{Spectroscopic and Photophysical Properties}

All the new compounds were characterized with various spectroscopic methods, including ${ }^{1} \mathrm{H}$ and ${ }^{13}$ C NMR spectroscopy (Figure S1-S11), as well as high-resolution mass spectrometry. The distyryl BODIPYs 1-4 and aza-BODIPY 5 showed a strong absorption in the near-infrared region (661-680 nm) in DMF, which is a desirable feature of photosensitizers that can prevent absorption by biomolecules and facilitate light penetration into tissues. Upon excitation at $610 \mathrm{~nm}$, these compounds showed a fluorescence emission at 679-719 nm. For the distyryl BODIPY series, the diiodo analogue 4 showed a slightly blue-shifted absorption band and significantly weaker fluorescence than the dibromo counterparts 1-3, which could be attributed to the heavy-atom effect. As summarized in Table 1, the absorption band of BODIPY 4 was blue-shifted to $661 \mathrm{~nm}$ and its fluorescence quantum yield $\left(\Phi_{\mathrm{F}}\right)$ was only 0.21 with reference to $\mathrm{ZnPc}$ in $\mathrm{DMF}\left(\Phi_{\mathrm{F}}=0.28\right)$, whereas the brominated analogues 
showed a red-shifted absorption band (up to $680 \mathrm{~nm}$ for BODIPY 2) and higher $\Phi_{\mathrm{F}}$ value (up to 0.42 for BODIPY 3). The spectral features of the aza-BODIPY 5 were remarkably different. The Stokes shift (14 nm vs. up to $39 \mathrm{~nm}$ for 2 ) and fluorescence quantum yield (0.01 vs. up to 0.42 for BODIPY 3) were significantly lower than those of BODIPYs 1-4. To evaluate their singlet oxygen generation efficiency, DPBF was used as the singlet oxygen scavenger. By monitoring the rate of photodegradation of this quencher in DMF, as reflected by the decrease in its absorbance at $415 \mathrm{~nm}$, the singlet oxygen quantum yield $\left(\Phi_{\Delta}\right)$ could be determined. As shown in Table 1, the weakly fluorescent distyryl BODIPY 4 and aza-BODIPY 5 showed significantly higher singlet oxygen quantum yield than the brominated analogues 1-3 as a result of the heavy-atom effect due to the iodo substituents.

Table 1. Electronic absorption and basic photophysical data for 1-5 in N,N-dimethylformamide (DMF).

\begin{tabular}{ccccc}
\hline Compound & $\lambda_{\max } / \mathbf{n m}(\log \varepsilon)$ & $\lambda_{\mathrm{em}} / \mathbf{n m}{ }^{\mathbf{a}}$ & $\mathbf{\Phi}_{\mathbf{F}}{ }^{\mathbf{a}, \mathbf{b}}$ & $\boldsymbol{\Phi}_{\Delta}{ }^{\mathrm{c}, \mathbf{d}}$ \\
\hline $\mathbf{1}$ & $319(4.47), 384(4.68), 441(4.18), 672(4.95)$ & 704 & 0.35 & 0.09 \\
$\mathbf{2}$ & $317(4.21), 389(4.39), 454(3.91), 680(4.68)$ & 719 & 0.30 & 0.07 \\
$\mathbf{3}$ & $320(4.16), 386(4.36), 443(3.87), 674(4.64)$ & 707 & 0.42 & 0.08 \\
$\mathbf{4}$ & $316(4.28), 379(4.40), 446(4.03), 661(4.60)$ & 690 & 0.21 & 0.54 \\
$\mathbf{5}$ & $439(3.66), 665(4.48)$ & 679 & 0.01 & 0.42 \\
\hline
\end{tabular}

\subsection{Assessment of In Vitro PD-MBC}

The photoinduced antibacterial activities of these BODIPY derivatives (compounds 1-5) were then examined against 16 MRSA strains by measuring the photodynamic minimal bactericidal concentrations (PD-MBC). The highest concentration tested for each photosensitizer was set as $100 \mu \mathrm{M}$, since it was believed that higher concentrations would not be feasible for further in vivo investigations. The pre-incubation time and illumination time were fixed at 120 and $20 \mathrm{~min}$, respectively, for the aPDT studies as determined by our previous investigations. It was found that the mono-cationic distyryl BODIPYs 1-3 showed comparatively lower $(p<0.05)$ anti-MRSA activity (Table 2$)$, which could be a result of their lower singlet oxygen quantum yields (0.07-0.09, Table 1). Surprisingly, despite the fact that the dicationic analogue 4 was an efficient singlet oxygen generator in $\operatorname{DMF}\left(\Phi_{\Delta}=0.54\right.$, Table 1$)$, its potency against the MRSA strains was also low (Table 2). By contrast, the aza-BODIPY 5 showed significantly lower $(p<0.05)$ MBC values against all the tested MRSA strains (except hospital-associated (HA) W231 strain), regardless of their respective antibiotic resistance and microbial type (Table 2). At concentrations of $\leq 100 \mu \mathrm{M}$, it could completely eradicate (PD-MBC) all the 16 MRSAs after illumination for $20 \mathrm{~min}\left(\lambda>610 \mathrm{~nm}, \sim 40 \mathrm{~mW} / \mathrm{cm}^{2}\right)$. For comparison, the benchmark photosensitizer methylene blue showed no statistically significant cell eradication under these conditions, and could only eradicate some of the strains when greater than 6-100-fold higher concentrations were used (typically $625 \mu \mathrm{M}$ or higher, Table 2). 
Table 2. Minimal bactericidal concentrations (MBCs) of 1-5 and methylene blue against 16 methicillin-resistant Staphylococcus aureus (MRSA) strains.

\begin{tabular}{|c|c|c|c|c|c|c|c|c|c|c|c|c|c|}
\hline \multirow[b]{2}{*}{ MRSA Type } & \multirow[b]{2}{*}{ MRSA Strain } & \multicolumn{2}{|c|}{ Compound 1} & \multicolumn{2}{|c|}{ Compound 2} & \multicolumn{2}{|c|}{ Compound 3} & \multicolumn{2}{|c|}{ Compound 4} & \multicolumn{2}{|c|}{ Compound 5} & \multicolumn{2}{|c|}{ Methylene Blue } \\
\hline & & PDT $(\mu \mathrm{M})$ & $\begin{array}{c}\text { No PDT } \\
(\mu \mathrm{M})\end{array}$ & $\operatorname{PDT}(\mu \mathrm{M})$ & $\begin{array}{c}\text { No PDT } \\
(\mu \mathrm{M})\end{array}$ & PDT $(\mu \mathrm{M})$ & $\begin{array}{c}\text { No PDT } \\
(\mu \mathrm{M})\end{array}$ & $\operatorname{PDT}(\mu \mathrm{M})$ & $\begin{array}{c}\text { No PDT } \\
(\mu \mathrm{M})\end{array}$ & PDT $(\mu \mathrm{M})$ & $\begin{array}{l}\text { No PDT } \\
(\mu \mathrm{M})\end{array}$ & PDT $(\mu \mathrm{M})$ & $\begin{array}{c}\text { No PDT } \\
(\mu \mathrm{M})\end{array}$ \\
\hline ATCC & 43300 & $>100^{a}$ & $>100$ & $>100$ & $>100$ & $>100$ & $>100$ & $>100$ & $>100$ & 25 & $>100$ & 625 & $>2500^{b}$ \\
\hline ATCC & BAA 42 & $>100$ & $>100$ & $>100$ & $>100$ & $>100$ & $>100$ & $>100$ & $>100$ & 12.5 & $50-100$ & 625 & $>2500$ \\
\hline ATCC & BAA 43 & $>100$ & $>100$ & $>100$ & $>100$ & $>100$ & $>100$ & $>100$ & $>100$ & 25 & $>100$ & $312.5-625$ & $>2500$ \\
\hline ATCC & BAA 44 & $>100$ & $>100$ & $>100$ & $>100$ & $>100$ & $>100$ & $>100$ & $>100$ & $12.5-25$ & $>100$ & $312.5-625$ & $>2500$ \\
\hline Mutant & $\mathrm{AAC}\left(6^{\prime}\right)-\mathrm{APH}\left(2^{\prime \prime}\right)$ & $>100$ & $>100$ & $>100$ & $>100$ & $>100$ & $>100$ & $>100$ & $>100$ & $25-50$ & $>100$ & $625-1250$ & $>2500$ \\
\hline Mutant & $\begin{array}{c}\text { RN4220 } \\
\text { /pUL5054 } \\
\end{array}$ & $>100$ & $>100$ & $>100$ & $>100$ & $>100$ & $>100$ & $>100$ & $>100$ & $12.5-25$ & 50 & $1250-2500$ & $>2500$ \\
\hline $\mathrm{CA}^{c}$ & W44 & $>100$ & $>100$ & $>100$ & $>100$ & $>100$ & $>100$ & $>100$ & $>100$ & $12.5-25$ & $50-100$ & 2500 & $>2500$ \\
\hline CA & W45 & $>100$ & $>100$ & $>100$ & $>100$ & $>100$ & $>100$ & $>100$ & $>100$ & $12.5-25$ & 50 & $1250-2500$ & $>2500$ \\
\hline $\mathrm{CA}$ & W46 & $>100$ & $>100$ & $>100$ & $>100$ & $>100$ & $>100$ & $>100$ & $>100$ & 25 & $>100$ & 2500 & $>2500$ \\
\hline $\mathrm{CA}$ & W47 & $>100$ & $>100$ & $>100$ & $>100$ & $>100$ & $>100$ & $>100$ & $>100$ & 25 & $50-100$ & 2500 & $>2500$ \\
\hline $\mathrm{CA}$ & W48 & $>100$ & $>100$ & $>100$ & $>100$ & $>100$ & $>100$ & $>100$ & $>100$ & $12.5-25$ & 50 & 2500 & $>2500$ \\
\hline $\mathrm{HA}^{d}$ & W231 & $>100$ & $>100$ & $>100$ & $>100$ & $>100$ & $>100$ & $>100$ & $>100$ & $50-100$ & $>100$ & 2500 & $>2500$ \\
\hline HA & W232 & $>100$ & $>100$ & $>100$ & $>100$ & $>100$ & $>100$ & $>100$ & $>100$ & 50 & $>100$ & 2500 & $>2500$ \\
\hline HA & W233 & $>100$ & $>100$ & $>100$ & $>100$ & $>100$ & $>100$ & $>100$ & $>100$ & $25-50$ & $>100$ & 2500 & $>2500$ \\
\hline HA & W234 & $>100$ & $>100$ & $>100$ & $>100$ & $>100$ & $>100$ & $>100$ & $>100$ & $25-50$ & $>100$ & 2500 & $>2500$ \\
\hline HA & W235 & $>100$ & $>100$ & $>100$ & $>100$ & $>100$ & $>100$ & $>100$ & $>100$ & 50 & $>100$ & 2500 & $>2500$ \\
\hline
\end{tabular}

${ }^{a}$ Highest concentration of BODIPY derivatives tested for MBC. ${ }^{b}$ Highest concentration of methylene blue tested for MBC. ${ }^{c}$ Community-associated. ${ }^{d}$ Hospital-associated. 


\section{Conclusions}

A series of cationic BODIPY derivatives were synthesized and evaluated for their antimicrobial photodynamic activity against a broad spectrum of MRSAs. They exhibited a strong absorption in the near-infrared region (661-680 nm) and could generate singlet oxygen in DMF. The singlet oxygen quantum yields of the diiodo analogues 4 and 5 were particularly high $(0.54$ and 0.42 , respectively) owing to the heavy-atom effect. Upon irradiation, the aza-BODIPY analogue 5 showed high potency against all the 16 MRSA strains examined, including several antibiotic-resistant and HA and CA strains, with MBCs ranging from 12.5 to $25 \mu \mathrm{M}$ (or 50-100 $\mu \mathrm{M}$ for the HA strains). Its aPDT efficiency was significantly higher than that of the clinically approved photosensitizer MB. The results suggested that aza-BODIPY 5 is a potential antimicrobial photodynamic therapeutic agent that is worthy of further investigation.

Supplementary Materials: Supplementary materials can be found at http://www.mdpi.com/2227-9059/8/6/140/s1. Figure S1: (a) ${ }^{1} \mathrm{H}$ and (b) ${ }^{13} \mathrm{C}\left\{{ }^{1} \mathrm{H}\right\}$ NMR spectra of 1 in DMSO- $d_{6}$, Figure S2: (a) ${ }^{1} \mathrm{H}$ and (b) ${ }^{13} \mathrm{C}\left\{{ }^{1} \mathrm{H}\right\}$ NMR spectra of 2 in DMSO- $d_{6}$, Figure S3: ${ }^{1} \mathrm{H}$ NMR spectrum of 3 in DMSO- $d_{6}$, Figure S4: ${ }^{1} \mathrm{H}$ NMR spectrum of 4 in DMSO- $d_{6}$, Figure S5: (a) ${ }^{1} \mathrm{H}$ and (b) ${ }^{13} \mathrm{C}\left\{{ }^{1} \mathrm{H}\right\}$ NMR spectra of 5 in $\mathrm{CDCl}_{3}$, Figure S6: (a) ${ }^{1} \mathrm{H}$ and (b) ${ }^{13} \mathrm{C}\left\{{ }^{1} \mathrm{H}\right\}$ NMR spectra of 8 in $\mathrm{CDCl}_{3}$, Figure S7: (a) ${ }^{1} \mathrm{H}$ and (b) ${ }^{13} \mathrm{C}\left\{{ }^{1} \mathrm{H}\right\}$ NMR spectra of 10 in DMSO- $d_{6}$, Figure S8: (a) ${ }^{1} \mathrm{H}$ and $(\mathrm{b}){ }^{13} \mathrm{C}\left\{{ }^{1} \mathrm{H}\right\}$ NMR spectra of 12 in $\mathrm{CDCl}_{3}$, Figure S9: (a) ${ }^{1} \mathrm{H}$ and (b) ${ }^{13} \mathrm{C}\left\{{ }^{1} \mathrm{H}\right\}$ NMR spectra of 14 in $\mathrm{CDCl}_{3}$, Figure S10: ${ }^{1} \mathrm{H}$ NMR spectrum of 18 in $\mathrm{CDCl}_{3}$, Figure S11: ${ }^{1} \mathrm{H}$ NMR spectrum of 19 in $\mathrm{CDCl}_{3}$.

Author Contributions: Conceptualization, K.-P.F., M.I., D.K.P.N., and C.B.S.L.; Data curation, P.D., R.C.H.W., J.W., and B.W.; Formal analysis, P.D., R.C.H.W., D.K.P.N., and M.I.; Performance of experiments, P.D. and R.C.H.W.; Funding acquisition, K.-P.F.; Writing-original draft, P.D.; Writing-review and editing, D.K.P.N., R.C.H.W., B.C.L.C., P.-C.L., and K.-M.L. All authors have read and agreed to the published version of the manuscript.

Funding: This work was mainly supported by a grant from the Health and Medical Research Fund (HMRF 16151202), and partly by the Si Yuan Foundation, HKSAR, China.

Conflicts of Interest: The authors declare no conflict of interest. The funders had no role in the design of the study; in the collection, analyses, or interpretation of data; in the writing of the manuscript, or in the decision to publish the results.

\section{Abbreviations}

$\begin{array}{ll}{ }^{1} \mathrm{H} N \mathrm{NR} & \text { proton nuclear magnetic resonance } \\ { }^{13} \mathrm{C}\left\{{ }^{1} \mathrm{H}\right\} \text { NMR } & \text { proton-decoupled carbon-13 nuclear magnetic resonance } \\ \text { aPDT } & \text { antimicrobial photodynamic therapy } \\ \text { ATCC } & \text { American Type Culture Collection } \\ \text { BODIPY } & \text { boron dipyrromethene } \\ \text { CA } & \text { community-associated } \\ \text { CFU } & \text { colony-forming unit } \\ \text { CLSI } & \text { Clinical and Laboratory Standards Institute } \\ \text { DMF } & \text { N,N-dimethylformamide } \\ \text { DMSO } & \text { dimethyl sulfoxide } \\ \text { ESI } & \text { electrospray ionization } \\ \text { HA } & \text { hospital-associated } \\ \text { HRMS } & \text { high-resolution mass spectrum } \\ \text { MALDI-TOF } & \text { matrix-assisted laser-desorption/ionization time-of-flight } \\ \text { MBC } & \text { minimum bactericidal concentration } \\ \text { MHB } & \text { Mueller-Hinton broth } \\ \text { MRSA } & \text { methicillin-resistant Staphylococcus aureus } \\ \text { MSSA } & \text { Methicillin-sensitive Staphylococcus aureus } \\ \text { NIR } & \text { near-infrared } \\ \text { PBS } & \text { phosphate buffer saline } \\ \text { ROS } & \text { reactive oxygen species } \\ \text { THF } & \text { tetrahydrofuran } \\ \text { TLC } & \text { thin-layer chromatography } \\ \lambda_{\text {max }} & \text { wavelength for absorption maxima } \\ \lambda_{\mathrm{em}} & \text { emission wavelength } \\ \varepsilon & \text { extinction coefficient } \\ \Phi_{\mathrm{F}} & \text { fluorescence quantum yield } \\ \Phi_{\Delta} & \text { singlet oxygen quantum yield } \\ & \end{array}$




\section{References}

1. Humphreys, H.; Coleman, D. Whole genome sequencing and the prevention and control of meticillin-resistant Staphylococcus aureus infection. J. Hosp. Infect. 2013, 85, 85-86. [PubMed]

2. Chuang, Y.-Y.; Huang, Y.-C. Molecular epidemiology of community-associated meticillin-resistant Staphylococcus aureus in Asia. Lancet Infect. Dis. 2013, 13, 698-708. [CrossRef]

3. Lowy, F.D. Staphylococcus aureus infections. N. Engl. J. Med. 1998, 339, 520-532. [PubMed]

4. Jevons, M.P. Celbenin-resistant staphylococci. Br. Med. J. 1961, 1, 124-125.

5. Deurenberg, R.H.; Stobberingh, E.E. The evolution of Staphylococcus aureus, Infection, genetics and evolution. J. Mol. Epidemiol. Evol. Genet. 2008, 8, 747-763. [CrossRef] [PubMed]

6. Vera, D.M.A.; Haynes, M.H.; Ball, A.R.; Dai, T.; Astrakas, C.; Kelso, M.J.; Hamblin, M.R.; Tegos, G.P. Strategies to Potentiate Antimicrobial Photoinactivation by Overcoming Resistant Phenotypes †. Photochem. Photobiol. 2012, 88, 499-511. [CrossRef]

7. Dai, T.; Huang, Y.-Y.; Hamblin, M.R. Photodynamic therapy for localized infections-State of the art. Photodiagnosis Photodyn. Ther. 2009, 6, 170-188.

8. Dai, T.; Fuchs, B.B.; Coleman, J.J.; Prates, R.A.; Astrakas, C.; Denis, T.G.S.; Ribeiro, M.S.; Mylonakis, E.; Hamblin, M.R.; Tegos, G.P. Concepts and Principles of Photodynamic Therapy as an Alternative Antifungal Discovery Platform. Front. Microbiol. 2012, 3, 21-26. [CrossRef]

9. Denis, T.G.S.; Dai, T.; Izikson, L.; Astrakas, C.; Anderson, R.R.; Hamblin, M.R.; Tegos, G.P. All you need is light. Virulence 2011, 2, 509-520.

10. Wainwright, M. 'Safe' photoantimicrobials for skin and soft-tissue infections. Int. J. Antimicrob. Agents 2010, 36, 14-18. [CrossRef]

11. Hamblin, M.R. Antimicrobial photodynamic inactivation: A bright new technique to kill resistant microbes. Curr. Opin. Microbiol. 2016, 33, 67-73. [PubMed]

12. Usacheva, M.N.; Teichert, M.C.; Biel, M.A. Comparison of the methylene blue and toluidine blue photobactericidal efficacy against gram-positive and gram-negative microorganisms. Lasers Surg. Med. 2001, 29, 165-173. [PubMed]

13. Wainwright, M.; Crossley, K. Methylene Blue-A Therapeutic Dye for All Seasons? J. Chemother. 2002, 14, 431-443. [CrossRef] [PubMed]

14. Liu, Y.; Qin, R.; Zaat, S.A.J.; Breukink, E.; Heger, M. Antibacterial photodynamic therapy: Overview of a promising approach to fight antibiotic-resistant bacterial infections. J. Clin. Trans. Res. 2015, 2, 21-26.

15. Dai, T.; Tegos, G.P.; Zhiyentayev, T.; Mylonakis, E.; Hamblin, M.R. Photodynamic therapy for methicillinresistant Staphylococcus aureus infection in a mouse skin abrasion model. Lasers Surg. Med. 2010, 42, 38-44. [CrossRef] [PubMed]

16. Bartolomeu, M.; Rocha, S.; Cunha, Â.; Neves, M.G.P.M.S.; Faustino, M.A.F.; Almeida, A. Effect of Photodynamic Therapy on the Virulence Factors of Staphylococcus aureus. Front. Microbiol. 2016, 7, 5-10. [CrossRef]

17. Moan, J.; Peng, Q. An outline of the hundred-year history of PDT. Photodyn. Ther. 2003, 23, 3591-3600.

18. Lauro, F.M.; Pretto, P.; Covolo, L.; Jori, G.; Bertoloni, G. Photoinactivation of bacterial strains involved in periodontal diseases sensitized by porphycene-polylysine conjugates. Photochem. Photobiol. Sci. 2002, 1, 468-470.

19. Grinholc, M.; Rapacka-Zdonczyk, A.; Rybak, B.; Szabados, F.; Bielawski, K.P. Multiresistant Strains Are as Susceptible to Photodynamic Inactivation as Their Naïve Counterparts: Protoporphyrin IX-Mediated Photoinactivation Reveals Differences Between Methicillin-Resistant and Methicillin-Sensitive Staphylococcus aureus Strains. Photomed. Laser Surg. 2014, 32, 121-129. [CrossRef]

20. Soncin, M.; Fabris, C.; Busetti, A.; Dei, D.; Nistri, D.; Roncucci, G.; Jori, G. Approaches to selectivity in the Zn(ii)-phthalocyanine-photosensitized inactivation of wild-type and antibiotic-resistant Staphylococcus aureus. Photochem. Photobiol. Sci. 2002, 1, 815-819.

21. Embleton, M.L. Selective lethal photosensitization of methicillin-resistant Staphylococcus aureus using an IgG-tin (IV) chlorin e6 conjugate. J. Antimicrob. Chemother. 2002, 50, 857-864. [CrossRef] [PubMed]

22. Darabpour, E.; Kashef, N.; Mashayekhan, S. Chitosan nanoparticles enhance the efficiency of methylene blue-mediated antimicrobial photodynamic inactivation of bacterial biofilms: An in vitro study. Photodiagnosis Photodyn. Ther. 2016, 14, 211-217. [CrossRef] [PubMed] 
23. Sharma, M.; Visai, L.; Bragheri, F.; Cristiani, I.; Gupta, P.K.; Speziale, P. Toluidine Blue-Mediated Photodynamic Effects on Staphylococcal Biofilms. Antimicrob. Agents Chemother. 2007, 52, 299-305. [CrossRef] [PubMed]

24. Ribeiro, A.P.D.; Pavarina, A.C.; Dovigo, L.N.; Brunetti, I.L.; Bagnato, V.S.; Vergani, C.E.; Costa, C.A.D.S. Phototoxic effect of curcumin on methicillin-resistant Staphylococcus aureus and L929 fibroblasts. Lasers Med. Sci. 2012, 28, 391-398. [CrossRef] [PubMed]

25. Makdoumi, K.; Bäckman, A. Photodynamic UVA-riboflavin bacterial elimination in antibiotic-resistant bacteria. Clin. Exp. Ophthalmol. 2016, 44, 582-586. [CrossRef]

26. García, I.; Ballesta, S.; Gilaberte, Y.; Rezusta, A.; Pascual, Á. Antimicrobial photodynamic activity of hypericin against methicillin-susceptible and resistant Staphylococcus aureus biofilms. Future Microbiol. 2015, 10, 347-356. [CrossRef]

27. Ziessel, R.; Ulrich, G.; Harriman, A. The Chemistry of Bodipy: A New El Dorado for Fluorescence Tools. Chem. Inform. 2007, 38, 12-18.

28. Loudet, A.; Burgess, K. ChemInform Abstract: BODIPY Dyes and Their Derivatives: Syntheses and Spectroscopic Properties. ChemInform 2008, 39, 1-8. [CrossRef]

29. Hendricks, J.A.; Keliher, E.J.; Wan, D.; Hilderbrand, S.A.; Weissleder, R.; Mazitschek, R. Synthesis of [18F]BODIPY: Bifunctional Reporter for Hybrid Optical/Positron Emission Tomography Imaging. Angew. Chem. 2012, 124, 4681-4684. [CrossRef]

30. Ortiz, M.J.; Agarrabeitia, A.R.; Duran-Sampedro, G.; Prieto, J.B.; Lopez, T.A.; Massad, W.A.; Montejano, H.A.; García, N.A.; Arbeloa, I.L. Synthesis and functionalization of new polyhalogenated BODIPY dyes. Study of their photophysical properties and singlet oxygen generation. Tetrahedron 2012, 68, 1153-1162. [CrossRef]

31. Frimannsson, D.O.; Grossi, M.; Murtagh, J.; Paradisi, F.; O'Shea, D.F. Light Induced Antimicrobial Properties of a Brominated Boron Difluoride (BF2) Chelated Tetraarylazadipyrromethene Photosensitizer. J. Med. Chem. 2010, 53, 7337-7343. [CrossRef]

32. Carpenter, B.; Situ, X.; Scholle, F.; Bartelmess, J.; Weare, W.; Ghiladi, R. Antiviral, Antifungal and Antibacterial Activities of a BODIPY-Based Photosensitizer. Molecules 2015, 20, 10604-10621. [CrossRef] [PubMed]

33. Martinez, S.R.; Palacios, Y.B.; Heredia, D.A.; Agazzi, M.L.; Durantini, A.M. Phenotypic resistance in photodynamic inactivation unravelled at the single bacterium level. ACS Infect. Dis. 2019, 5, 1624-1633. [CrossRef] [PubMed]

34. Jung, H.S.; Han, J.; Shi, H.; Koo, S.; Singh, H.; Kim, H.-J.; Sessler, J.L.; Lee, J.Y.; Kim, J.-H.; Kim, J.S. Overcoming the limits of hypoxia in photodynamic therapy: A carbonic anhydrase IX-targeted approach. J. Am. Chem. Soc. 2017, 139, 7595-7602. [CrossRef] [PubMed]

35. Jeyakumar, K.; Chand, D.K. Ring-opening reactions of epoxides catalyzed by molybdenum(VI) dichloride dioxide. Synthesis 2008, 5, 807-819.

36. He, H.; Ng, D.K.P. A ratiometric near-infrared $\mathrm{pH}$-responsive fluorescent dye based on distyryl BODIPY. Org. Biomol. Chem. 2011, 9, 2610-2613. [CrossRef]

37. Amombo, G.M.O.; Kramer, T.; Monte, F.L.; Göring, S.; Fach, M.; Smith, S.; Kolb, S.; Schubenel, R.; Baumann, K.; Schmidt, B. Modification of a promiscuous inhibitor shifts the inhibition from $\gamma$-secretase to FLT-3. Bioorg. Med. Chem. Lett. 2012, 22, 7634-7640. [CrossRef]

38. Wang, Q.; Ng, D.K.P.; Lo, P.-C. Functional aza-boron dipyrromethenes for subcellular imaging and organelle-specific photodynamic therapy. J. Mater. Chem. B 2018, 6, 3285-3296. [CrossRef]

39. Eaton, D.F. Reference materials for fluorescence measurement. Pure Appl. Chem. 1988, 60, 1107-1114. [CrossRef]

40. Maree, M.D.; Kuznetsova, N.; Nyokong, T.J. Silicon octaphenoxyphthalocyanines: Photostability and singlet oxygen quantum yields. J. Photochem. Photobiol. A Chem. 2001, 140, 117-125. [CrossRef]

41. Ross, J.I.; Eady, E.A.; Cove, J.H.; Cunliffe, W.J.; Baumberg, S.; Wootton, J.C. Inducible erythromycin resistance in staphlyococci is encoded by a member of the ATP-binding transport super-gene family. Mol. Microbiol. 1990, 4, 1207-1214. [CrossRef] [PubMed]

42. Ip, M.; Yung, R.W.H.; Ng, T.K.; Luk, W.K.; Tse, C.; Hung, P.; Enright, M.; Lyon, D.J. Contemporary Methicillin-Resistant Staphylococcus aureus Clones in Hong Kong. J. Clin. Microbiol. 2005, 43, 5069-5073. [PubMed]

43. Li, J.; Wang, L.; Ip, M.; Sun, M.; Sun, J.; Huang, G.; Wang, C.; Deng, L.; Zheng, Y.; Fu, Z.; et al. Molecular and Clinical Characteristics of Clonal Complex 59 Methicillin-Resistant Staphylococcus aureus Infections in Mainland China. PLoS ONE 2013, 8, e70602. [CrossRef] [PubMed] 
44. Wong, J.; Ip, M.; Tang, A.; Wei, V.; Wong, S.; Riley, S.; Read, J.; Kwok, K. Prevalence and risk factors of community-associated methicillin-resistant Staphylococcus aureus (CA-MRSA) carriage in Asia-Pacific region from 2000 to 2016: A systematic review and meta-analysis. Int. J. Infect. Dis. 2018, 73, 135-136.

45. Clinical and Laboratory Standards Institute (CLSI). Performance Standards for Antimicrobial Susceptibility Testing, 29th ed.; CLSI supplement M100; Clinical and Laboratory Standards Institute: Wayne, PA, USA, 2019.

46. Wang, D.; Liu, R.; Chen, C.; Wang, S.; Chang, J.; Wu, C.; Zhu, H.; Waclawik, E.R. Synthesis, photophysical and electrochemical properties of aza-boron-diquinomethene complexes. Dye. Pigment. 2013, 99, 240-249.

(C) 2020 by the authors. Licensee MDPI, Basel, Switzerland. This article is an open access article distributed under the terms and conditions of the Creative Commons Attribution (CC BY) license (http://creativecommons.org/licenses/by/4.0/). 